\title{
Life Cycle Design Evaluation and Application of Common Power Transmission Tower Material
}

\author{
Yuanjing Deng \\ China Electrical Power Research Institute \\ Beijing, China \\ e-mail: dengyuanjing@epri.sgcc.com.cn
}

Qi Ma

Electric Power Research Institute of State Grid Qinghai

Electrical Power Company

Xining, China

e-mail: 420583728@qq.com

Kaiquan Xia

China Electrical Power Research Institute

Beijing, China

e-mail: xiakq@epri.sgcc.com.cn

\author{
Zhiqing Ma \\ Electric Power Research Institute of State Grid Qinghai \\ Electrical Power Company \\ Xining, China \\ e-mail: xundian123@sohu.com
}

\begin{abstract}
This paper takes common material (including Q345、Q420angle steel, Q345、Q420 large size angle steel, Q345、Q420、Q460 steel pipe) of tower in $500 \mathrm{kV}$ transmission lines as the object to carry out the application technology of life design evaluation and comprehensive comparison research. According to the State Grid guidelines for transmission line of whole life cycle design and construction (for Trial Implementation), the economic and technical evaluation of different tower material are carried out in 6 indexes of whole life cycle design evaluation by fuzzy hierarchy evaluation method, and the life cycle assessment and discuss of different material in design scheme of $500 \mathrm{kV}$ transmission lines tower are analyzed and evaluated.
\end{abstract}

Keywords - tower materials; fuzzy hierarchy evaluation;weight vector; life cycle design; assessment;

\section{INTRODUCTION}

Life cycle design technology of the power transmission lines extends traditional design method to the whole life cycle of projects. Comprehensive performance design is carried out for design, construction, operation, maintenance and out of service in whole process, and design with optimum general performance of safety and reliability, economy, saving and environment protection and other index are proposed. Projects involves many parts. A large quantity of research and practice show that even though design cost only shares less in life cycle cost of engineering, influence degree on engineering cost can reach $75 \% \sim 85 \%$. Therefore design is a significant part which affects life cycle management of the whole engineering project. Infrastructure construction department of
State Grid has issued Technical guide on life cycle design and construction of power transmission line (Trial) in 2013.

Angle steel and steel pipe of several common materials (including Q345, Q420 angle steel, Q345 and Q420 large specification angle steel, Q345 and Q420 steel pipe) are applied in the power transmission tower in the $500 \mathrm{kV}$ power transmission line as research objects in this paper. Evaluation different power transmission tower materials are processed for 6 indexes according to life cycle design evaluation idea in Technical guide on life cycle design and construction of power transmission line (Trial) of State Grid. Application of life cycle evaluation in material aspect of the power transmission tower is forwarded, cases of the power transmission tower design plan with different terrain and different material are analyzed, compared and selected, and suggestion is also proposed.

\section{EVALUATION METHOD AND STEP OF LIFE CYCLE DESIGN}

Life cycle design of the power transmission line is required to consider planning, design, construction and operation as a whole according to Technical guide on life cycle design and construction of power transmission line (Trial) issued and implemented by infrastructure construction department of State Grid, which specifies safety and reliability, economy, technology , save and environment protection within life cycle. Starting from engineering practice, actively apply mature new technology, new material, new engineering process to carry out technical and economic comparison of the technical plan of the route, conductor(earth wire), insulator, fitting, lightning proof grounding, power transmission tower and foundation 
elements within life cycle, and realize optimum life cycle cost. Life cycle design of the power transmission line shall carry out life cycle cost calculation according to designed application years, and evaluate its safety and reliability, maintenance, extendibility, saving and environment protection, implementation and recoverable index. detail.

Refer to table I for application life of every component for

TABLE I. APPLICATION LIFE OF COMMON POWER TRANSMISSION LINE COMPONENT UNDER GENERAL ENVIRONMENT (UNIT: YEAR)

\begin{tabular}{|l|l|l|l|}
\hline ITEM & CONDUCTOER & INSULATOR & TOWER \\
\hline YEARS & 40 & $20-40$ & 40 \\
\hline ITEM & FITTINGS & $\begin{array}{l}\text { EARTHING } \\
\text { WIRE }\end{array}$ & FOUNDATION \\
\hline YEARS & $20-40$ & $20-40$ & 60 \\
\hline
\end{tabular}

Life cycle design evaluation of the power transmission line is a very complicated problem. Because several components in the power transmission line shall be considered and factors affecting every component varies. So evaluation and decision issues during actual engineering practice generally contain a large quantity of factors which cannot be qualified, mathematic model which is formed by simplification can't reflect all influence factors completely. For these evaluation decision issues including many complicate influence factors and including factors not measured quantitatively, analytic hierarchy process and fuzzy comprehensive evaluation method provide effective way during evaluation decision. Much information of factors is incomplete and unclear, and certain fuzzy is expressed in comprehensive evaluation relationship, fuzzy comprehensive evaluation method can transfer qualitative evaluation of every factor to quantitative evaluation, and single factor self-evaluation is carried out. The "fuzzy hierarchy evaluation method" which is combined by analytic hierarchy process and fuzzy comprehensive evaluation method is taken as life cycle design evaluation method of the power transmission line.

Basic steps for life cycle evaluation are shown as following:

(1) Establish hierarchy system; (2) Build decision table of factors; (3) Constitute judgment comparison matrix by 1-9 class; (4) Check matrix consistency; (5) Solve maximum eigenvalue and weight vector; (6) Calculate comprehensive weight; (7) Carry out single factor evaluation, form membership function and form evaluation matrix R; (8) Weight vector and evaluation matrix are composed as comprehensive evaluation vector, calculate evaluation score and carry out comprehensive evaluation.

\section{WEIGHT DETERMINATION AND CLASSIFICATION OF INDEX BELONGING CLASS}

\section{A. Weight judgment matrix}

Analyze relationship between each evaluation index, weight judgment matrix by means of 1-9 class table on basis of summarizing score and discussion conditions of every expert is given in table II.

TABLE II. WEIGHT JUDGMENT MATRIX

\begin{tabular}{|l|c|c|c|c|c|c|}
\hline $\begin{array}{l}\text { Class } \\
\text { Level }\end{array}$ & $\begin{array}{c}\text { Safety \& } \\
\text { reliability }\end{array}$ & $\begin{array}{c}\text { Econ } \\
\text { omy }\end{array}$ & $\begin{array}{c}\text { Impleme } \\
\text { ntation }\end{array}$ & $\begin{array}{c}\text { Mai } \\
\text { nten } \\
\text { ance }\end{array}$ & $\begin{array}{c}\text { Environ } \\
\text { mental } \\
\text { Friendly }\end{array}$ & $\begin{array}{c}\text { Recy } \\
\text { cle }\end{array}$ \\
\hline $\begin{array}{c}\text { Safety \& } \\
\text { reliability }\end{array}$ & 1 & 3 & 6 & 7 & 8 & 9 \\
\hline Economy & $1 / 3$ & 1 & 4 & 6 & 7 & 8 \\
\hline $\begin{array}{c}\text { Implemen } \\
\text { tation }\end{array}$ & $1 / 6$ & $1 / 4$ & 1 & 3 & 4 & 5 \\
\hline $\begin{array}{c}\text { Maintena } \\
\text { nce }\end{array}$ & $1 / 7$ & $1 / 6$ & $1 / 3$ & 1 & 2 & 3 \\
\hline $\begin{array}{c}\text { Environm } \\
\text { ental }\end{array}$ & $1 / 8$ & $1 / 7$ & $1 / 4$ & $1 / 2$ & 1 & 2 \\
\hline Friendly & $1 / 9$ & $1 / 8$ & $1 / 5$ & $1 / 3$ & $1 / 2$ & 1 \\
\hline Recycle & & & & & & 2 \\
\hline
\end{tabular}

\section{B. Inspection consistency}

Obtain maximum eigenvalue $\lambda_{\max }=6.3485$;

The consistency inspection has been processed.

\section{Obtain weight vector}

Characteristic vector corresponding to maximum eigenvalue, weight vector is normalized as $\omega=\left(\begin{array}{llllll}0.4746 & 0.2795 & 0.1178 & 0.0596 & 0.0402 & 0.0283\end{array}\right)$;

\section{Weight description}

Weights of safety and reliability, economy, implementation, maintenance, saving and environment protection, recoverable in life cycle comprehensive evaluation are $0.4746,0.2795,0.1178,0.0596,0.0402$ and 0.0283 respectively. It shall be considered that practical construction difficulty increasing caused by terrain reason. In particularly to mountain terrain, determine weight vector $\omega=\left(\begin{array}{llllll}0.4655 & 0.1548 & 0.2241 & 0.0745 & 0.0480 & 0.0331\end{array}\right)$;

Above two vectors are general weight of safety and reliability, economy, implementation, maintenance, saving and environment protection and recycle 6 indexes during design of the power transmission tower under general condition, life cycle evaluation weight of the concrete engineering can be adjusted according to concrete conditions.

\section{E. Evaluation class principle based on comprehensive fuzzy evaluation method.}

In order to distinguish life cycle design evaluation of the power transmission tower in different plan, life cycle design evaluation of the power transmission tower is classified as I, II, III and IV four class which are corresponding to excellent, good, general and bad, refer to table III. 
Taking evaluation factors of safety and economy, economy as sample and give out class classification at same time, refer to table IV and V.

TABLE III. COMPREHENSIVE EVALUATION PRINCIPLE FOR LIFE CYCLE DESIGN OF POWER TRANSMISSION TOWER

\begin{tabular}{|l|c|c|c|c|}
\hline Class & I $(\mathbf{8 0})$ & II $(\mathbf{7 0})$ & III $(\mathbf{6 0})$ & IV $(\mathbf{5 0})$ \\
\hline Degree & Excellent & Very good & General & Bad \\
\hline
\end{tabular}

TABLE IV. CLASS PRINCIPLE OF SAFETY AND RELIABILITY

\begin{tabular}{|l|c|c|c|l|}
\hline Class & I (80) & II (70) & III (60) & IV (50) \\
\hline \multirow{3}{*}{ Degree } & $\begin{array}{c}\text { High Safty } \\
\text { and } \\
\text { Reliability }\end{array}$ & $\begin{array}{c}\text { Good Safty } \\
\text { and } \\
\text { Reliability }\end{array}$ & $\begin{array}{c}\text { Basic Safty } \\
\text { and } \\
\text { Reliability }\end{array}$ & $\begin{array}{l}\text { Bad Safty } \\
\text { and } \\
\text { Reliability }\end{array}$ \\
\hline
\end{tabular}

TABLE V. CLASS PRINCIPLE OF ECONOMY

\begin{tabular}{|l|c|c|c|l|}
\hline Class & I (80) & II (70) & III (60) & IV (50) \\
\hline \multirow{3}{*}{ Degree } & Excellent & Good & Basic & Bad \\
& Economy & Economy & Economy & Economy \\
& Performance & Performance & Performance & Performance \\
\hline
\end{tabular}

Refer to table VI and figure 1 for concrete safety and reliability evaluation details and function.

TABLE VI. EVALUATION RULES SAFETY AND RELIABILITY

\begin{tabular}{|c|c|c|}
\hline Class & Degree & Evaluation rules \\
\hline I & $\begin{array}{c}\text { High Safty } \\
\text { and } \\
\text { Reliability }\end{array}$ & Design reliability of tower $\beta>3.7$ \\
\hline II & $\begin{array}{c}\text { Good Safty } \\
\text { and } \\
\text { Reliability }\end{array}$ & Design reliability of tower $2.7 \leq \beta \leq 3.2$ \\
\hline III & $\begin{array}{c}\text { Basic Safty } \\
\text { and } \\
\text { Reliability }\end{array}$ & Design reliability of tower $\beta<2.7$ \\
\hline IV & $\begin{array}{c}\text { Bad Safty } \\
\text { and } \\
\text { Reliability }\end{array}$ & \\
\hline
\end{tabular}

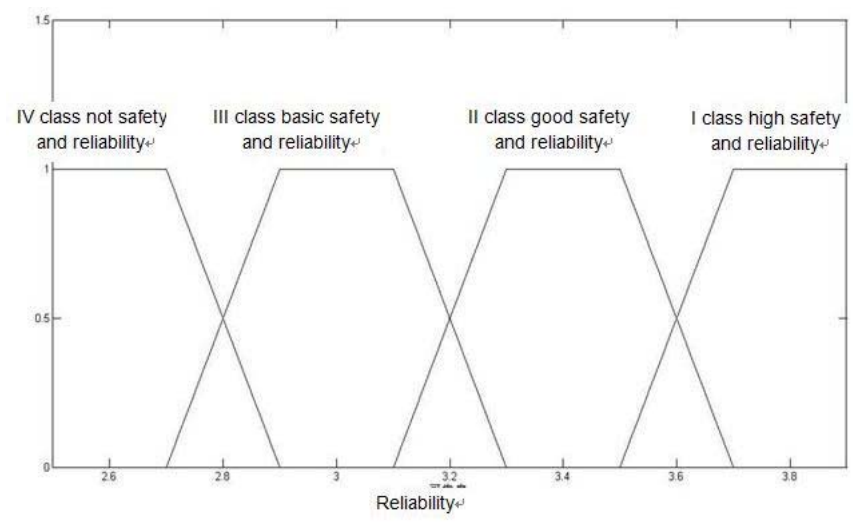

Fig. 1. Safety and reliability belonging function of power transmission tower

LCC (LifeCycle Cost $)=\mathrm{C}_{\mathrm{OT}}+W_{T}+F_{T}+D_{T}$
$C_{O T}$--Cost of construction; $W_{T}$-- Cost of maintenance and inspection; $F_{T}$-- Cost of failure; $D_{T}$-- Cost of recovery.

In which, electricity prince is valued as 0.47 Yuan $/ \mathrm{kW}$, social discount rate $\mathrm{R}$ takes $4.00 \%$, inflation rate $\mathrm{r}$ takes $3.50 \%$. When procurement cost of steel material is calculated, material cost of angle steel is $8000 \mathrm{Yuan} / \mathrm{t}$, material cost of steel pipe is 12000 Yuan/t. Life of the power transmission tower takes 40 years according to application life in Technical guide on life cycle design and construction of power transmission line (Trial).Refer to Budget rating of grid inspection engineering for concrete cost of single minor repair, bolt tightening and painting item of the power transmission tower. Refer to Budget rating of grid removal engineering for removal cost of the power transmission tower and the auxiliary facilities.

\section{CASE STUDY}

Take 5C plan in General Cost of power transmission and transformation engineering in State Grid Corporate as sample, select flat floor, high mountain and steep hill two kinds of terrains as concrete cases, carry out life cycle design, comparison, selection and evaluation of the power transmission tower material Q420 angle steel, Q345 angle steel, Q345 steel pipe and Q460 steel pipe.

5C - flat floor plan applies Q420 angle steel material. Constitute Q420 angle steel evaluation matrix as following table according to single factor evaluation details of 6 indexes, and solve comprehensive evaluation vector:

$B_{1}=\omega \cdot R=\left(\begin{array}{llllll}0.4746 & 0.2795 & 0.1178 & 0.0596 & 0.0402 & 0.0283\end{array}\right) \cdot\left[\begin{array}{cccc}0 & 1 & 0 & 0 \\ 0 & 0 & 1 & 0 \\ 1 & 0 & 0 & 0 \\ 1 & 0 & 0 & 0 \\ 0 & 0 & 1 & 0 \\ 0 & 0.5 & 0.5 & 0\end{array}\right]$

$=\left(\begin{array}{llll}0.1774 & 0.48875 & 0.33385 & 0\end{array}\right)$

The mark of its life cycle design evaluation is $0.1774 \times 80+0.48875 \times 70+0.33385 \times 60=68.436$.

In plan $5 \mathrm{C}$ - flat and mountain terrain, carry out evaluation about several common materials according to above methods, and obtain excellence sequence of life cycle design comprehensive evaluation as following: Q420 angle steel, Q460 steel pipe, Q345 steel pipe, Q345 angle steel.

\section{CONCLUSION}

In this paper, weight relationship of 6 evaluation indexes (safety and reliability, economy, implementation, maintenance, saving and environment protection, recycle) is determined as $\omega=\left(\begin{array}{llllll}0.4746 & 0.2795 & 0.1178 & 0.0596 & 0.0402 & 0.0283\end{array}\right) \quad$ in flat, hill, general mountain, river network and mire according to life cycle design and evaluation ideas in Technical guide on life cycle design and construction of power transmission line (Trial); its weight is adjusted to mountain terrain, weight vector

$$
\omega=\left(\begin{array}{llllll}
0.4655 & 0.1548 & 0.2241 & 0.0745 & 0.0480 & 0.0331
\end{array}\right) \text {; }
$$

Life cycle design evaluation of the power transmission tower with different materials in typical schemes of $5 \mathrm{C}$ in 
general costing of power transmission and transformation engineering of State Grid Corporate are carried out. And its ranking results evaluation of common materials in flat, hill and high mountain terrain are: Q420 angle steel, Q460 steel pipe, Q345 steel pipe and Q345 angle steel.

\section{References}

[1] ShuaiJunqing Editor in chief. Life cycle management theory, method and application of asset of power enterprise [M]. Beijing : China Power Press, 2010

[2] Technical guide for life cycle design and construction of power transmission line (trial) Infrastructure department of State Grid Corporate

[3] GuoYongfeng Editor in chief. Construction technology of power transmission line [M]. Beijing: China Power Press 2014
[4] Pan Weiwei Fang XuchuWuoGuowei etc. Life cycle process management and application of grid asset [M]. Beijing: China Power Press, 2013

[5] Liu Zhenya Editor in chief. General construction cost of 110-750kV power transmission and transformation engineering of State Grid Corporate[M]. Beijing: China Power Press, 2010

[6] JeffBerman..Maximizing project value:defining, managing, and measuring for optimal retum.NewYork,NY:Amacom, Ameriean Management Assoeiation, 2007.

[7] Alain Bemard.Methods and tools for effeetive knowledge life- cyelemanagement.NewYork:Springer,2008.

[8] Guoqing.Discuss on life cycle management of transmission project[J].Shanxi Electricity,2007(12):88-92

[9] Rujie,Wenlingchang. Application of life cycle analysis on selection of overhead transmisison lineFs[J].Shaanxi Electricity,2007(12):49-54

[10] JohnStark.GlobalProduct:strategy,Produet life cyele management and the billion customer question.London:Springer,2007. 